COMMENT

\title{
The future of low-temperature carbon dioxide electrolysis depends on solving one basic problem
}

\author{
Joshua A. Rabinowitz (iD ${ }^{1} \&$ Matthew W. Kanan (iD ${ }^{1 凶}$
}

Carbonate formation is the primary source of energy and carbon losses in lowtemperature carbon dioxide electrolysis. Realigning research priorities to address the carbonate problem is essential if this technology is to become a viable option for renewable chemical and fuel production.

The plummeting cost and daily curtailment of renewable electricity have spurred growing interest in using $\mathrm{CO}_{2}$ electrolysis to produce chemicals and fuels. High-temperature solid oxide cells that convert $\mathrm{CO}_{2}$ to $\mathrm{CO}$ and $\mathrm{O}_{2}$ have reached nascent commercialization. Low-temperature $\mathrm{CO}_{2}$ electrolysis is an attractive alternative that offers more convenient and flexible operation and the ability to generate multicarbon products such as ethylene, ethanol, and propanol. Over the past 10 years, a dramatic expansion of research in this area has yielded substantial progress in fundamental understanding and prototype devices. Leveraging insights from fuel cells and membrane water electrolyzers, researchers have developed gas diffusion electrode (GDE) cells demonstrating synthetically relevant $\mathrm{CO}_{2}$ electrolysis current densities $\left(>100 \mathrm{~mA} \mathrm{~cm}^{-2}\right)$ and promising stability. Despite these advances, the energy efficiency (power-to-product) and carbon efficiency $\left(\mathrm{CO}_{2}\right.$-toproduct) of low-temperature $\mathrm{CO}_{2}$ electrolysis remain too low to support large-scale applications ${ }^{1,2}$. While much current research is focused on $\mathrm{CO}_{2}$ reduction catalyst design, the biggest obstacle to improving performance is an often overlooked basic chemistry problem: the rapid and thermodynamically favorable reaction of $\mathrm{CO}_{2}$ with hydroxide $\left(\mathrm{OH}^{-}\right)$to form carbonate $\left(\mathrm{CO}_{3}{ }^{2-}\right)$ imposes steady state electrolysis conditions that result in large voltage and $\mathrm{CO}_{2}$ losses. Although recent work has brought attention to some aspects of the $\mathrm{CO}_{3}{ }^{2-}$ problem ${ }^{2-4}$, it is far more pernicious than what is widely appreciated. Here we explain how $\mathrm{CO}_{3}{ }^{2-}$ formation compromises efficiency to highlight the need for new research directions that address this problem.

\section{Hydroxide consumption makes alkaline $\mathrm{CO}_{2}$ electrolyzers fuel-wasting devices}

The state-of-the-art for low-temperature $\mathrm{CO}_{2}$ electrolysis has been obscured by studies that utilize a reservoir of flowing alkaline electrolyte to maintain a high $\mathrm{pH}$ in the cell ${ }^{5-8}$. High $\mathrm{pH}$ minimizes the cell voltage, which makes these systems appear to have high energy efficiency, but consumption of $\mathrm{OH}^{-}$in the reservoir by $\mathrm{CO}_{3}{ }^{2-}$ formation results in a net negative energy balance. Understanding why the cell voltage is minimized at high $\mathrm{pH}$ helps to clarify the $\mathrm{CO}_{3}{ }^{2-}$ problem (Fig. 1a). For most known catalyst materials, including $\mathrm{Au}$ and $\mathrm{Cu}$, the $\mathrm{CO}_{2}$ reduction rate depends on the electron transfer driving force but not explicitly on $\mathrm{pH}^{9-13}$. As a result, synthetically relevant current densities require rather negative potentials versus an absolute reference such as the standard hydrogen electrode (SHE). Even with high surface area electrodes, $\mathrm{CO}_{2}$ reduction at a geometric current density of $>200 \mathrm{~mA} \mathrm{~cm}^{-2}$ has generally required potentials

\footnotetext{
${ }^{1}$ Department of Chemistry, Stanford University, 337 Campus Drive, Stanford, CA 94305, USA. ${ }^{凶}$ email: mkanan@stanford.edu
} 


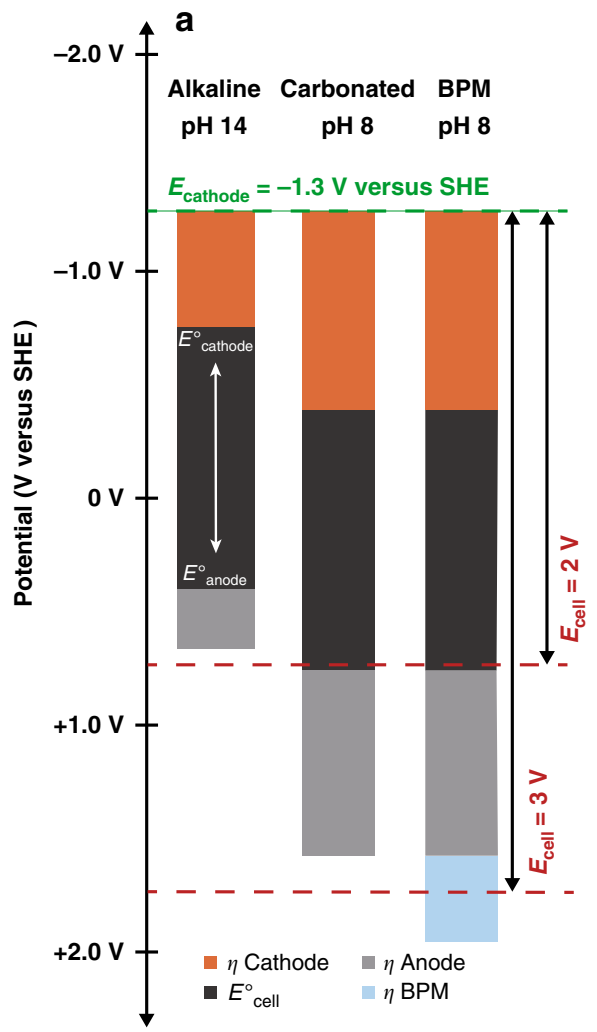

b

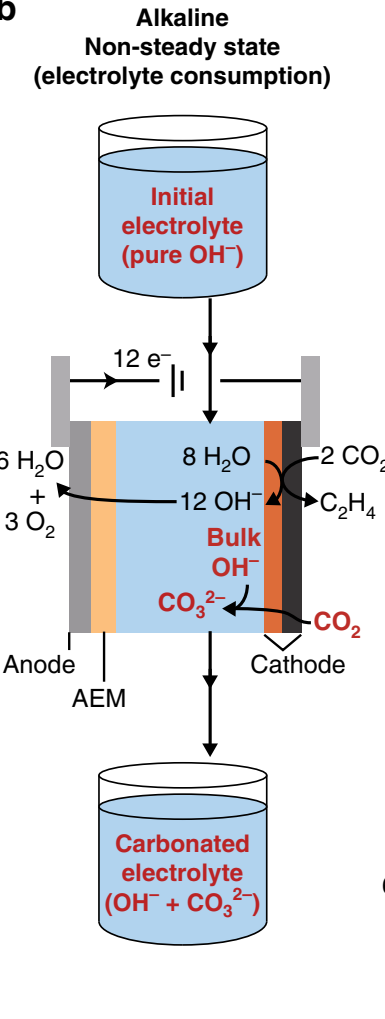

C
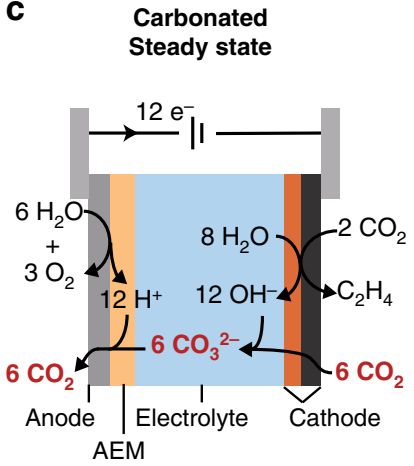

d

BPM

Steady state

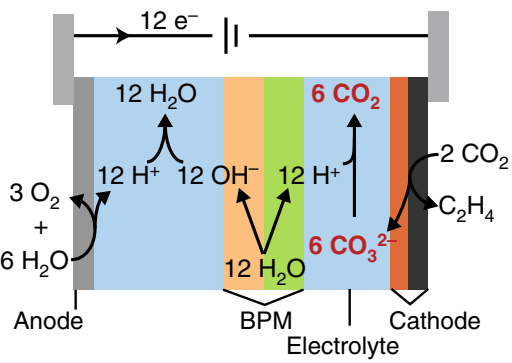

Fig. 1 The $\mathrm{CO}_{3}{ }^{2-}$ problem. a Visualization of various contributors to the cell voltage for a $\mathrm{CO}_{2}$ electrolysis cell operating under alkaline conditions, carbonated conditions, or with a bipolar membrane (BPM). The contributions shown are the thermodynamic cell potential ( $E^{\circ}{ }_{\text {cell }}$ ), and cathode, anode, and BPM overpotentials $(\eta)$. Electrode potentials are referenced to the SHE scale. For simplicity, cell resistance was not included, which would add to the cell voltage. The green dotted line represents the least negative cathode potential reported for low-temperature $\mathrm{CO}_{2}$ reduction at $>200 \mathrm{mAcm}{ }^{-2} 7$. The red dotted lines provide a visual reference for cell voltages. The thermodynamic potentials for the cathode $\left(E^{\circ}{ }_{\text {cathode }}\right)$ and anode $\left(E_{\text {anode }}^{\circ}\right)$ shift positive versus $\mathrm{SHE}$ as the $\mathrm{pH}$ is decreased. Alkaline conditions minimize cell voltage but cannot be maintained at steady state because of $\mathrm{CO}_{3}{ }^{2-}$ formation. $\mathbf{b}$ Schematic of anion transport in an alkaline flow cell showing $\mathrm{OH}^{-}$consumption by $\mathrm{CO}_{2}$. c Schematic of a cell at steady state after carbonation showing the carbon loss due to $\mathrm{CO}_{2}$ released at the anode. $\mathbf{d}$ Schematic of a BPM cell at steady state.

$<-1.3 \mathrm{~V}$ versus SHE. Because the thermodynamic electrode potentials become more negative versus SHE as the $\mathrm{pH}$ is increased, the cathode overpotential is minimized by increasing $\mathrm{pH}$ at a fixed cathode potential versus SHE. The overpotential for oxygen evolution at the anode is also generally lowest in base. These contributions significantly reduce the cell voltage at high $\mathrm{pH}$ (Fig. 1a).

While minimizing cell voltage is obviously desirable, cells operating under flowing alkaline conditions are not at steady state. The $\mathrm{OH}^{-}$in the electrolyte reservoir is continuously consumed by exergonic $\mathrm{CO}_{3}{ }^{2-}$ formation as it contacts $\mathrm{CO}_{2}$ at the cathode (Eq. $1^{14}$ and Fig. 1b):

$$
2 \mathrm{OH}^{-}{ }_{(\mathrm{aq})}+\mathrm{CO}_{2(\mathrm{~g})} \rightarrow \mathrm{CO}_{3}{ }^{2-}{ }_{(\mathrm{aq})}+\mathrm{H}_{2} \mathrm{O}_{(\mathrm{l})} \Delta G^{\circ}=-56 \mathrm{~kJ} \mathrm{~mol}^{-1}
$$

In practice, the energy required to regenerate $\mathrm{CO}_{2}$ and $2 \mathrm{OH}^{-}$ from aqueous $\mathrm{CO}_{3}{ }^{2-}$ is much larger than $\left|\Delta G^{\circ}\right|$, for example $>230 \mathrm{~kJ} \mathrm{~mol}^{-1}$ with an optimized system using a calcination cycle ${ }^{15}$. Depending on the product, the energy stored by $\mathrm{CO}_{2}$ electrolysis is $\sim 100-130 \mathrm{~kJ} \mathrm{~mol}^{-1}$ of electrons. Thus, the energy balance with flowing alkaline electrolyte will be negative if carbonation consumes $\sim 1 \mathrm{OH}^{-}$equivalent for each electron of $\mathrm{CO}_{2}$ electrolysis current. Though it is rarely quantified, one recent study reported that $\sim 3 \mathrm{OH}^{-}$were consumed per electron of $\mathrm{CO}_{2}$ to- $\mathrm{CO}$ electrolysis current with a flowing $1 \mathrm{M} \mathrm{KOH}$ electrolyte ${ }^{8}$. Unfortunately, it is common practice to ignore $\mathrm{OH}^{-}$consumption and calculate an "energy efficiency" based solely on the applied voltage, thermodynamic voltage, and faradaic efficiency. These values are qualitatively incorrect. In reality, flowing alkaline $\mathrm{CO}_{2}$ electrolysis cells are fuel-wasting devices because it would require more fuel to regenerate the spent electrolyte than the amount of fuel produced by the electrolysis. Using data from flowing alkaline conditions in technoeconomic analyses will grossly overestimate the state-of-the-art for $\mathrm{CO}_{2}$ electrolysis.

\section{Consequences of operating in carbonated electrolyte}

Conversion of power to fuel with a positive energy balance requires operating under steady state conditions where there is no net electrolyte consumption. In a cell operating at steady state, $\mathrm{CO}_{3}{ }^{2-}$ is still formed continuously at the cathode by reaction of $\mathrm{CO}_{2}$ with the electrogenerated $\mathrm{OH}^{-}$, but it is protonated elsewhere in the cell to release $\mathrm{CO}_{2}$. In an anion-transporting cell such as an anion exchange membrane (AEM) cell, $\mathrm{CO}_{3}{ }^{2-}$ is transported to the anode (Fig. 1c). In order to protonate $\mathrm{CO}_{3}{ }^{2-}$, the anode $\mathrm{pH}$ equilibrates to near-neutral $(\mathrm{pH} \sim 8)^{2}$, which increases the cell voltage compared to high $\mathrm{pH}$ because the anode thermodynamic potential moves in the positive direction (Fig. 1a). In addition, there is a much greater oxygen evolution overpotential at near-neutral $\mathrm{pH}$ with available catalysts. Thus, most of the energy penalty from the $\mathrm{CO}_{3}{ }^{2-}$ problem is a consequence of what happens at the anode. In fact, the same problem is seen in AEM water electrolysis, where the cathode catalyzes $\mathrm{H}_{2}$ evolution. Contamination of an AEM water electrolyzer with trace amounts of air $\left(400 \mathrm{ppm} \mathrm{CO}_{2}\right)$ results in the formation of $\mathrm{CO}_{3}{ }^{2-}$, which causes a $>1 \mathrm{~V}$ increase to the cell voltage ${ }^{16}$. 
The steady state carbon flux imposed by $\mathrm{CO}_{3}{ }^{2-}$ formation also sets an upper limit on carbon efficiency in anion transporting cells. For $\mathrm{CO}_{2}$ reduction to $\mathrm{CO}$, one $\mathrm{CO}_{2}$ is released at the anode for every $\mathrm{CO}$ that is produced at the cathode, resulting in a maximum carbon efficiency of $50 \%$. For ethylene, the maximum is $25 \%$ (Fig. 1c). Many cells operate at much lower carbon efficiencies than these maxima because a large excess of $\mathrm{CO}_{2}$ is supplied to the cathode to support high current densities. Low carbon efficiency is a major barrier to large-scale chemical and fuel electrosynthesis because there is a substantial energy and financial cost to obtain a $\mathrm{CO}_{2}$ feedstock of suitable purity.

An alternative to an anion transporting cell is to operate with a bipolar membrane (BPM) configured such that $\mathrm{CO}_{2}$ electrolysis is coupled with water dissociation at the BPM. At steady state, $\mathrm{CO}_{3}{ }^{2-}$ generated at the cathode is protonated at the BPM interface, releasing $\mathrm{CO}_{2}$ on the cathode side (Fig. 1d). While this design avoids releasing $\mathrm{CO}_{2}$ at the anode ${ }^{17}$, it has a lower energy efficiency than an AEM cell because the BPM imposes an additional overpotential in order to drive water dissociation (Fig. 1a). It is important to note that $\mathrm{CO}_{2}$ crossover through a BPM is low but non-zero ${ }^{18}$. As such, BPM cells that start with high $\mathrm{pH}$ on the anode side will transform to a $\mathrm{CO}_{3}{ }^{2-}$ electrolyte at steady state.

\section{Current state-of-the-art and outlook}

The consequences of the $\mathrm{CO}_{3}{ }^{2-}$ problem are evident in the performance that has been demonstrated at steady state. For the production of $\mathrm{CO}$, the best reported performance is for lab-scale $\left(5 \mathrm{~cm}^{2}\right)$ devices that have been operated at steady state for $>4000 \mathrm{~h}$ at $\sim 200 \mathrm{~mA} \mathrm{~cm}^{-2} \mathrm{CO}_{2}$-to-CO current density, nicely demonstrating the viability of durable $\mathrm{CO}$ electrosynthesis at a reasonable rate. However, the carbon efficiency is $50 \%$ and the cell voltage is $3.0 \mathrm{~V}$, corresponding to an energy efficiency of only $43 \% \%^{1,19}$. Both of these values are consistent with the analysis in Fig. 1. To make a more reduced product such as ethylene, the $\mathrm{CO}_{3}{ }^{2-}$ problem is more pronounced. The best reported performance at steady state is $60 \mathrm{~h}$ of operation at $\sim 500 \mathrm{~mA} \mathrm{~cm}^{-2} \mathrm{CO}_{2}$-to-ethylene current density, $\sim 2 \%$ carbon efficiency, and a cell voltage of $3.9 \mathrm{~V}$, corresponding to an energy efficiency of $\sim 15 \%{ }^{20}$. The evaluation of full cell metrics under steady state conditions remains uncommon in $\mathrm{CO}_{2}$ electrolysis research, but such experiments are essential for assessing progress and should become standard to demonstrate the impact of a material or design advance.

Low-temperature $\mathrm{CO}_{2}$ electrolysis will not be competitive with other electrical energy storage or $\mathrm{CO}_{2}$ conversion technologies without major gains in energy and carbon efficiency. Reducing the overpotential of $\mathrm{CO}_{2}$ reduction catalysis remains an important objective provided it can be realized under steady state conditions at high current density. Avoiding the losses imposed by $\mathrm{CO}_{3}{ }^{2-}$ formation demands a much broader research effort that includes strategies to control the formation and clearance of $\mathrm{CO}_{3}{ }^{2-}$, creative cell designs, and far greater attention to the anode. The progress on the $\mathrm{CO}_{3}{ }^{2-}$ problem will determine the trajectory of $\mathrm{CO}_{2}$ electrolysis in the next 10 years and its impact beyond the laboratory.

Received: 31 August 2020; Accepted: 25 September 2020;

Published online: 16 October 2020

\section{References}

1. Küngas, R. Review-Electrochemical $\mathrm{CO}_{2}$ reduction for $\mathrm{CO}$ production: comparison of low- and high-temperature electrolysis technologies. J. Electrochem. Soc. 167, 044508 (2020).

2. $\mathrm{Ma}, \mathrm{M}$. et al. Insights into the carbon balance for $\mathrm{CO}_{2}$ electroreduction on $\mathrm{Cu}$ using gas diffusion electrode reactor designs. Energy Environ. Sci 13, 977 (2020).

3. Weng, L. C., Bell, A. T. \& Weber, A. Z. Towards membrane-electrode assembly systems for $\mathrm{CO}_{2}$ reduction: A modeling study. Energy Environ. Sci. 12, 1950-1968 (2019).
4. Ripatti, D. S., Veltman, T. R. \& Kanan, M. W. Carbon monoxide gas diffusion electrolysis that produces concentrated $\mathrm{C}_{2}$ products with high single-pass conversion. Joule 3, 240-256 (2019).

5. Dinh, C.-T. et al. $\mathrm{CO}_{2}$ electroreduction to ethylene via hydroxide-mediated copper catalysis at an abrupt interface. Science 360, 783-787 (2018).

6. Zhong, M. et al. Accelerated discovery of $\mathrm{CO}_{2}$ electrocatalysts using active machine learning. Nature 581, 178-183 (2020).

7. $\mathrm{Ma}, \mathrm{W}$. et al. Electrocatalytic reduction of $\mathrm{CO}_{2}$ to ethylene and ethanol through hydrogen-assisted C-C coupling over fluorine-modified copper. Nat. Catal. 3, 478-487 (2020).

8. Cheng, W.-H. et al. $\mathrm{CO}_{2}$ reduction to $\mathrm{CO}$ with $19 \%$ efficiency in a solar-driven gas diffusion electrode flow cell under outdoor solar illumination. ACS Energy Lett. 5, 470-476 (2020).

9. Jan Schouten, K. P., Pérez Gallent, E. \& Koper, M. T. The influence of pH on the reduction of $\mathrm{CO}$ and $\mathrm{CO}_{2}$ to hydrocarbons on copper electrodes. J. Electroanal. Chem. 716, 53-57 (2014).

10. Wuttig, A., Yaguchi, M., Motobayashi, K., Osawa, M. \& Surendranath, Y. Inhibited proton transfer enhances Au-catalyzed $\mathrm{CO}_{2}$-to-fuels selectivity. Proc. Natl. Acad. Sci. USA 113, e4585-E4593 (2016).

11. Verma, S. et al. Insights into the low overpotential electroreduction of $\mathrm{CO}_{2}$ to $\mathrm{CO}$ on a supported gold catalyst in an alkaline flow electrolyzer. ACS Energy Lett. 3, 193-198 (2018).

12. Liu, $\mathrm{X}$. et al. $\mathrm{pH}$ effects on the electrochemical reduction of $\mathrm{CO}_{2}$ towards $\mathrm{C}_{2}$ products on stepped copper. Nat. Commun. 10, 1-10 (2019).

13. Ringe, $\mathrm{S}$. et al. Double layer charging driven carbon dioxide adsorption limits the rate of electrochemical carbon dioxide reduction on Gold. Nat. Commun. 11, 1-11 (2020).

14. Dean, J. A. Lange's Handbook of Chemistry, Vol. 15 (McGraw-Hill, 1992).

15. Keith, D. W., Holmes, G., St Angelo, D. \& Heidel, K. A process for capturing $\mathrm{CO}_{2}$ from the atmosphere. Joule 2, 1573-1594 (2018).

16. Parrondo, J. et al. Degradation of anion exchange membranes used for hydrogen production by ultrapure water electrolysis. RSC Adv. 4, 9875-9879 (2014).

17. Ma, M., Kim, S., Chorkendorff, I. \& Seger, B. Role of ion-selective membranes in the carbon balance for $\mathrm{CO}_{2}$ electroreduction via gas diffusion electrode reactor designs. Chem. Sci. https://doi.org/10.1039/d0sc03047c (2020).

18. Zhou, $\mathrm{X}$. et al. Solar-driven reduction of $1 \mathrm{~atm}$ of $\mathrm{CO}_{2}$ to formate at $10 \%$ energy-conversion efficiency by use of a $\mathrm{TiO}_{2}$-protected III- $\mathrm{V}$ tandem photoanode in conjunction with a bipolar membrane and a $\mathrm{Pd} / \mathrm{C}$ cathode. ACS Energy Lett. 1, 764-770 (2016).

19. Liu, Z., Yang, H., Kutz, R. \& Masel, R. I. $\mathrm{CO}_{2}$ electrolysis to $\mathrm{CO}$ and $\mathrm{O}_{2}$ at high selectivity, stability and efficiency using sustainion membranes. J. Electrochem. Soc. 165, 3371-3377 (2018).

20. Pelayo García de Arquer, F. et al. $\mathrm{CO}_{2}$ electrolysis to multicarbon products at activities greater than $1 \mathrm{~A} \mathrm{~cm}^{-2}$. Science 367, 661-666 (2020).

\section{Author contributions}

M.W.K. and J.A.R. developed the concept, wrote the comment, and prepared the figure.

\section{Competing interests}

The authors declare no competing interests.

\section{Additional information}

Correspondence and requests for materials should be addressed to M.W.K.

Reprints and permission information is available at http://www.nature.com/reprints

Publisher's note Springer Nature remains neutral with regard to jurisdictional claims in published maps and institutional affiliations.

\footnotetext{
Open Access This article is licensed under a Creative Commons Attribution 4.0 International License, which permits use, sharing, adaptation, distribution and reproduction in any medium or format, as long as you give appropriate credit to the original author(s) and the source, provide a link to the Creative Commons license, and indicate if changes were made. The images or other third party material in this article are included in the article's Creative Commons license, unless indicated otherwise in a credit line to the material. If material is not included in the article's Creative Commons license and your intended use is not permitted by statutory regulation or exceeds the permitted use, you will need to obtain permission directly from the copyright holder. To view a copy of this license, visit http://creativecommons.org/ licenses/by/4.0/.
}

(C) The Author(s) 2020 